\title{
-Original-
}

\section{Effects of Gefitinib on Radiation-induced Lung Injury in Mice}

\author{
Chunyan Wang, Shinji Abe, Kuniko Matsuda, Changhe Yu, \\ Yingji Li, Jiro Usuki, Arata Azuma and Shoji Kudoh \\ Department of Pulmonary Medicine/Infection and Oncology, Graduate School of Medicine, Nippon Medical School
}

\begin{abstract}
Clinical studies have demonstrated that gefitinib, an epidermal growth factor receptor inhibitor, is an effective treatment for some patients with advanced non-small cell lung cancer and is generally well-tolerated. However, several reports have also suggested that gefitinib is associated with acute lung injury and subsequent fibrosis. One hypothesis is that gefitinib exacerbates lung injury induced by radiation therapy. It is important to confirm the safety of gefitinib in radiotherapy for patients with lung cancer. In this preclinical study we aimed to clarify the effect of gefitinib on thoracic radiotherapy. Six-week-old female C57BL/ 6 mice were immobilized in a plastic frame, and the thorax was irradiated once with a dose of 12 Gy on day 0 . Gefitinib (20, 90 and $200 \mathrm{mg} / \mathrm{kg} /$ day) was administered on days 0 to 5 (acute phase) or days 14 to 19 (late phase) postirradiation. Thoracic irradiation induced lung injury and subsequent fibrosis 5 months later. Gefitinib, administered in the acute phase, had no effect on lung fibrosis or collagen levels induced by irradiation. A high dose of gefitinib $(200 \mathrm{mg} / \mathrm{kg} /$ day $)$ administered during the late phase significantly reduced fibrosis scores and collagen levels. These results suggest that gefitinib does not exacerbate radiation-induced lung injury and fibrosis in this strain of mice. Therefore, thoracic irradiation is unlikely to be a risk factor for lung injury associated with gefitinib treatment.
\end{abstract}

(J Nippon Med Sch 2008; 75: 96-105)

Key words: gefitinib, epidermal growth factor receptor, radiation-induced lung injury

\section{Introduction}

Gefitinib, an epidermal growth factor receptor (EGFR) inhibitor, is a novel molecularly targeted agent and an effective treatment for some patients with advanced non-small cell lung cancer (NSCLC) ${ }^{1,2}$. Gefitinib is generally well tolerated and is not typically associated with the cytotoxic side-effects commonly seen with chemotherapy ${ }^{3}$. However, gefitinib has been reported to be associated with interstitial pneumonia in Japan, with an incidence of $1.8 \%$ to $5.4 \%$. This rate is much higher than that in non-Japanese patients treated with gefitinib ${ }^{4-6}$. The mechanism of interstitial pneumonia associated with gefitinib treatment remains unknown. Lung specimens obtained at autopsy have shown diffuse alveolar damage associated with gefitinib treatment ${ }^{4}$. Radiation therapy for NSCLC might be a risk factor for interstitial pneumonia associated with gefitinib. In this study, we developed an experimental model of radiation-induced lung injury and subsequent

Correspondence to Shinji Abe, Internal Medicine, Department of Pulmonary Medicine/Infection and Oncology,

Nippon Medical School, 1-1-5 Sendagi, Bunkyo-ku, Tokyo 113-8603, Japan

E-mail: sabe@nms.ac.jp

Journal Website (http://www.nms.ac.jp/jnms/) 
fibrosis in mice. We investigated the effect of gefitinib at different doses and phases using this model.

\section{Materials and Methods}

\section{Animal Model of Lung Fibrosis by Thoracic Irradiation}

The experimental protocol was approved by the Animal Care Committee of Nippon Medical School. Six-week-old female C57BL/6 mice were purchased from Nippon CLEA (Tokyo, Japan). A model for radiation-induced lung fibrosis was generated as described previously ${ }^{7}$. A plastic frame was used to hold nonanesthetized mice, and lead strips were placed to shield all parts of the body except the thoracic region. The thoraxes were irradiated with a single dose of 12 Gy on Day 0 using X-ray equipment (MBR-1505R2, Hitachi Medico Technology, Tokyo, Japan). The irradiation parameters were as follows: a dose-rate at $2.4 \mathrm{~Gy} /$ minute at $150 \mathrm{kV}$, and a $0.4-\mathrm{m}$ source-to-surface distance as described previously with minor modifications?

\section{Mice Treatment}

Gefitinib (Iressa, 20, 90 and $200 \mathrm{mg} / \mathrm{kg} /$ day; donated by Astra Zeneca, Macclesfield, UK) was suspended in $0.1 \%$ Tween 80 solution (Sigma-Aldrich, St. Louis, MO) and given by gastrogavage once a day from day 0 to day 5 (acute phase) or day 14 to day 19 (late phase) postirradiation. Each experimental group comprised 6 mice. For the control group, a daily dose of vehicle $(0.1 \%$ Tween 80) was given by gastrogavage. Animals were allocated to 8 groups as follows:

1) gefitinib $(20,90$, or $200 \mathrm{mg} / \mathrm{kg} /$ day) alone (days 0-5)

2) irradiation (12 Gy) + vehicle (days 0-5)

3) irradiation (12 Gy) $+20 \mathrm{mg} / \mathrm{kg}$ of gefitinib during the acute phase (day $0-5$ )

4) irradiation (12 Gy) $+90 \mathrm{mg} / \mathrm{kg}$ of gefitinib during the acute phase (days $0-5$ )

5) irradiation (12 Gy) $+200 \mathrm{mg} / \mathrm{kg}$ of gefitinib during the acute phase (days 0-5)

6) irradiation (12 Gy) $+20 \mathrm{mg} / \mathrm{kg}$ of gefitinib during the late phase (days 14-19)

7) irradiation (12 Gy) $+90 \mathrm{mg} / \mathrm{kg}$ of gefitinib during the late phase (days 14-19)

8) irradiation (12 Gy) $+200 \mathrm{mg} / \mathrm{kg}$ of gefitinib during the late phase (days 14-19)

Six mice in each group were killed at 1, 2, 4, and 5 months postirradiation in both the acute-phase and late-phase experiments. Mice were killed with inhalation of ether.

In the irradiation model used in this study, gene expression of transforming growth factor beta (TGF$\beta$ ) was up-regulated in both the early (within 24 hours) and late (2-4 weeks) phases ${ }^{7}$. Because TGF- $\beta$ is the major cytokine responsible for the fibrotic reaction in lung fibrosis, these two phases were used to investigate the effect of gefitinib on irradiationinduced lung injuries.

\section{Histology and Fibrosis Score}

Mice were killed and extensively perfused via the right ventricle with $6 \mathrm{ml}$ of sterile phosphatebuffered saline (PBS) to eliminate blood cells. The left lung was fixed in $10 \%$ buffered formalin, embedded in paraffin, and stained with hematoxylin and eosin for routine histologic examination. The remaining sections of the left lung were processed for immunohistochemical studies. The severity of lung fibrosis was evaluated with the Ashcroft score as described previously ${ }^{8}$. Briefly, the entire field of each 10 sections of the left lung was scanned at a magnification of $\times 100$, and each field was graded visually from 0 (normal lung) to 8 (total fibrotic obliteration of the field). The mean value of the grades obtained for all fields was then used as the visual fibrosis score.

\section{Sircol Assay}

The Sircol collagen assay (Biocolor Ltd., Newtownabbey, Northern Ireland, UK) was performed as described previously ${ }^{9}$. For the Sircol collagen assay, the right lung $(n=3$, in each experimental group) was quickly frozen in liquid nitrogen and saved at $-80^{\circ} \mathrm{C}$ until use. The collagen content was collected for right-lung protein content. 


\section{Wang, et al}

\section{Immunohistochemical Studies}

Lung sections were double-immunostained for proliferating cell nuclear antigen (PCNA) and epithelial marker surfactant-associated protein antigen (SP-C). The sections were irradiated in a microwave oven in a $0.01 \mathrm{M}$ sodium citrate buffer to retrieve epitopes. After the nonspecific binding sites were blocked with $10 \%$ normal goat serum, the sections were incubated with a polyclonal antibody against pulmonary surfactant protein C $\quad(1: 200$ dilution; Santa Cruz Biotechnology, Inc., Santa Cruz, CA, USA) for 30 minutes at $40^{\circ} \mathrm{C}$ followed by a reaction with anti-rabbit IgG conjugated with a horseradish peroxidase-labeled polymer (1:500 dilution; Santa Cruz) and 3,3'-diaminobenzidine. After immersion in $0.1 \mathrm{M}$ glycine- $\mathrm{HCl}$ buffer $(\mathrm{PH} 2.2)$ for 2 hours to remove the prior antibody complex, the slides were incubated with a monoclonal antibody against PCNA (1:100 dilution; Santa Cruz) for 30 minutes at $40^{\circ} \mathrm{C}$ and reacted with an anti-mouse IgG conjugated with an alkaline phosphatase-labeled polymer (1:500 dilution; Santa Cruz) for $15 \mathrm{~min}$ at $40^{\circ} \mathrm{C}$. Immunoreactants were visualized with a solution containing 5-bromo-4-chloro-3-indoxyl phosphate and nitro blue tetrazolium chloride solution (BCIP/NBT kit IV; Vector Laboratories, Burlingame, CA, USA).

Semiquantitative analysis of epithelial proliferation was performed with the double-stained lung tissue. In brief, each lung sample was quantified in 5 to 8 randomly selected microscopic fields $($ at $\times 200$ magnification). The average percentages of cells positive for both PCNA and SP-C in the cytokeratinpositive cell population was regarded as epithelial proliferation index.

Double-immunostaining for EGFR and phosphorylated EGFR (p-EGFR) was performed after the retrieval of epitopes and the blocking of nonspecific binding sites using a method similar to that described above. Lung sections were primarily incubated with polyclonal antibodies against EGFR (1 : 20 dilution; Santa Cruz) and against p-EGFR (Tyr 1068; $1: 20$ dilution; Cell Signaling Technology, Beverly, MA, USA) for 30 minutes at $40^{\circ} \mathrm{C}$. For secondary staining, tissue sections were incubated with anti-rabbit IgG conjugated with horseradish peroxidase-labeled polymer (1:500 dilution; Sant Cruz) for 15 minutes at $40^{\circ} \mathrm{C}$. Cells positive for EGFR and p-EGFR were visualized with 3,3' diaminobenzidine in lung sections, which were counter stained with a hematoxylin solution. Negative control specimens were prepared by immunostaining using serum with no immunity as the primary antibodies. Semiquantitative evaluation of both EGFR- and p-EGFR-positive cells was performed according to the method of Putti et $\mathrm{al}^{10}$. The scoring of EGFR or p-EGFR staining was performed as follows: "0 points" for negative staining, "1 point" for $<10 \%$ positive cells, " 2 points" for $10 \%$ to $50 \%$ positive cells, and " 3 points" for $>50 \%$ positive cells.

\section{Western Blot Analysis}

Western blot analysis was performed using a standard procedure ${ }^{11}$. Protein quantification was determined by using a BCA Protein Assay kit (Pierce Biotechnology, Rockford, IL, USA). Mouse lung lysates, containing $25 \mu \mathrm{g}$ of protein, were boiled for 5 minutes in sodium dodecylsulfate sample buffer, separated with $12.5 \%$ sodium dodecylsulfate polyacrylamide gel electrophoresis, and transferred to a nitrocellulose membrane (Bio-Rad Laboratories, Hercules, CA, USA) using an electroblot apparatus (Bio-Rad Laboratories). Endogenous peroxidase activity was blocked by immersing the membrane in $5 \%$ not-fat dry milk with Tris-buffered saline with Tween-20 for 1 hour at room temperature on an orbital shaker, and the membranes were incubated overnight at $4{ }^{\circ} \mathrm{C}$ with the primary antibody against p-EGFR (1 : 250 dilution, Cell Signaling Technology). The membranes were then incubated in the secondary antibody horseradish peroxidaseconjugated with IgG (1:1,000 dilution, Santa Cruz) at room temperature for 1 hour. The protein blot was detected with the ECL Plus system (GE Healthcare Bio-Science Corp, Piscataway, NJ, USA).

\section{Statistical Analysis}

The Statistical analysis of differences among the groups was done by one-way ANOVA and post-hoc comparison with Tukey's test or Fisher's PLSD test for multiple comparisons using "Statistica" software 

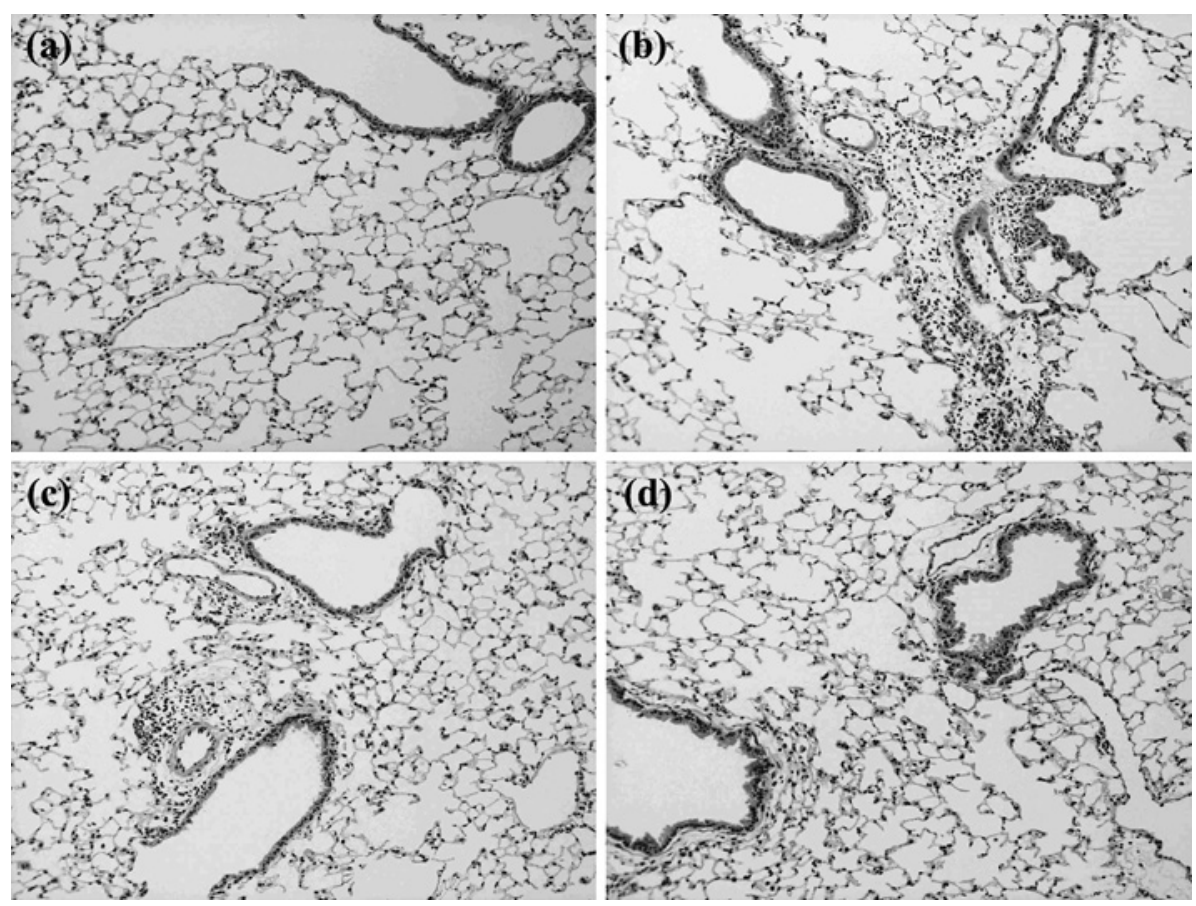

Fig. 1 Pathological changes in radiation-induced lung fibrosis treated with gefitinib Hematoxylin-eosin stained lung tissues from mice obtained 5 months postirradiation. (a) control (without radiation), (b) radiation only (12 Gy), (c) gefitinib (200 mg/kg) administered in the acute phase after radiation, (d) gefitinib $(200 \mathrm{mg} / \mathrm{kg}$ ) administered in the late phase after radiation. These photographs are representative of 5 mice in each group.

(StatSoft, Tulsa, OK). All data were expressed as the mean \pm SE. $\mathrm{p}<0.05$ was considered statistically significant.

\section{Results}

\section{Irradiation-induced Lung Fibrosis}

As shown in Figure 1, thickening of the alveolar wall, infiltration of inflammatory cells and fibrosis of alveolar septa were observed 5 months postirradiation, especially in subpleural regions (Fig. 1b). There were no differences in survival or body weight between the experimental groups.

\section{Effect of Gefinitib on Lung Fibrosis Induced by Irradiation}

Histopathologic examination showed that in both phases high-dose gefitinib (90 or $200 \mathrm{mg} / \mathrm{kg}$ ) tended to decrease irradiation-induced lung fibrosis (Fig. 1c and 1d). As shown in Figure 2, compared with irradiation-induced lung fibrosis (Ashcroft score, 2.33 $\pm 0.47)$, high dose of gefitinib $(200 \mathrm{mg} / \mathrm{kg})$ in the late phase significantly inhibited lung fibrosis (Ashcroft score, $0.80 \pm 0.45 ; \mathrm{p}=0.0038) 5$ months postirradiation. To quantify lung fibrosis, collagen deposition was measured with the Sircol assay. A high dose of gefitinib $(200 \mathrm{mg} / \mathrm{kg})$ in the late phase significantly reduced lung collagen levels compared with those in irradiated-lung fibrosis (Fig. 3, $\mathrm{p}<0.01$ ). There was no significant difference in either the lung fibrosis score or collagen deposition except, for high dose of gefitinib at late phase.

\section{Effect of Gefitinib on Epithelial Cell}

\section{Proliferation}

Immunostaining with both PCNA and SP-C was used to examine the effect of gefitinib on the proliferation of alveolar epithelial cells. In all mice, alveolar epithelial cells double-immunostained for both PCNA and SP-C were detected (Fig. 4A). Thoracic irradiation increased the number of $\mathrm{PCNA}^{+} / \mathrm{SP}_{-} \mathrm{C}^{+}$alveolar cells. There was no significant difference in the proportion of $\mathrm{PCNA}^{+} /$ SP-C ${ }^{+}$alveolar cells between the mice treated with irradiation alone and those treated with irradiation plus gefitinib in the acute phase. The proportion of 


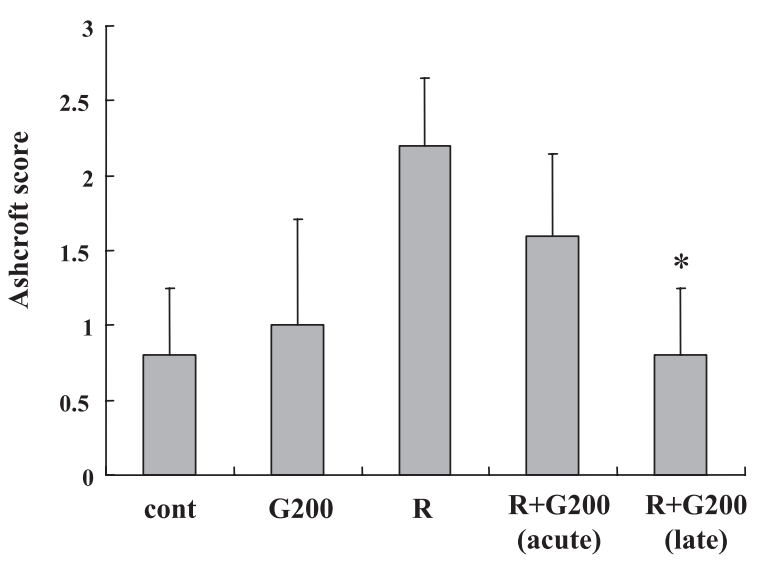

Fig. 2 Effect of gefitinib on lung fibrosis scores (Ashcroft scores)

Ashcroft scores of lung tissues obtained from mice 5 months postirradiation. Data represent the means \pm SEM of 5 mice in each group. Control: vehicle $(0.1 \%$ Tween solution), G200 (gefitinib alone $200 \mathrm{mg} / \mathrm{kg} / \mathrm{d}$ ), $\mathrm{R}$ : radiation only (12 Gy), $\mathrm{R}+\mathrm{G} 200$ (acute): gefitinib (200 $\mathrm{mg} / \mathrm{kg}$ ) administered in the acute phase postirradiation, R+G200 (late): gefitinib $(200 \mathrm{mg} / \mathrm{kg})$ administered in the late phase postirradiation. $p=0.0038$ versus mice treated with gefitinib $(200 \mathrm{mg} / \mathrm{kg} / \mathrm{d})$ in the late phase postirradiation and radiation only.

$\mathrm{PCNA}^{+} / \mathrm{SP}_{-} \mathrm{C}^{+}$alveolar cells was significantly decreased when high-dose gefitinib $(200 \mathrm{mg} / \mathrm{kg} /$ day) was administered in the late phase (Fig. 4B).

\section{Effect of Gefitinib on EGFR and p-EGFR Expression}

In mice treated with irradiation, airway epithelial cells and type II pneumocytes were immunostained with EGFR (Fig. 5Aa). Gefitinib did not change the expression of EGFR induced by irradiation (Fig. 5 Ab). On the other hand, gefitinib tended to inhibit the expression of p-EGFR (Fig. 5Ad) induced by irradiation. There was a significant difference in the labeling index of p-EGFR between the mice treated with irradiation alone and mice treated with irradiation and high-dose gefitinib in the late phase (Fig. 5B). Gefitinib treatment in both phases inhibited the expression of p-EGFR induced by irradiation (Fig. 6). Four to 5 months postirradiation there was no clear difference in p-EGFR expression between acute-phase treatment and late-phase treatment with gefitinib.

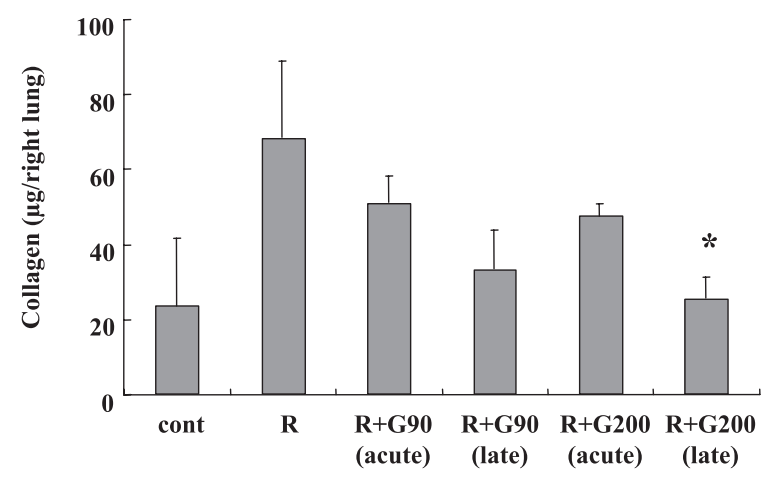

Fig. 3 Effect of gefitinib on collagen content Collagen content in lung tissues from mice obtained 5 months postirradiation. Data represent the mean \pm SEM of 5 mice in each group. Control: vehicle $(0.1 \%$ Tween solution), R: radiation alone, $\mathrm{R}+\mathrm{G} 90$ (acute): gefitinib $(90 \mathrm{mg} / \mathrm{kg}$ ) administered in the acute phase postirradiation, $\mathrm{R}+\mathrm{G} 200$ (acute): gefitinib (200 mg/kg) administered in the acute phase postirradiation, $\mathrm{R}+\mathrm{G} 90$ (late): gefitinib $(90 \mathrm{mg} / \mathrm{kg}$ ) administered in the late phase postirradiation, R+G200 (late): gefitinib (200 $\mathrm{mg} / \mathrm{kg}$ ) administered in the late phase postirradiation. High-dose $(200 \mathrm{mg} / \mathrm{kg} / \mathrm{d})$ gefitinib at late phase significantly reduced collagen deposition levels compared with radiation only $(\mathrm{p}<0.01)$.

\section{Discussion}

To our knowledge this is the first report of the effects of gefitinib on irradiation-induced lung injury and fibrosis in mice. In this study, we demonstrated that gefitinib has no effect on lung-fibrosis or collagen levels induced by irradiation. However, lung fibrosis scores and collagen levels were significantly reduced when high-dose gefitinib $(200 \mathrm{mg} / \mathrm{kg} /$ day $)$ was administered during the late phase.

Gefitinib, a selective inhibitor of the EGFR tyrosine kinase, is an effective treatment for some patients with advanced NSCLC ${ }^{1.2}$. However, severe lung injury associated with gefitinib treatment has been reported in some Japanese patients ${ }^{4-6}$, although the mechanism by which this injury occurs remains unclear. One possible mechanism is the previous alveolar damage caused by the radiotherapy delivered prior to gefitinib treatment. In an animal model with ICR mice, gefitinib has been reported to augment bleomycin-induced pulmonary fibrosis ${ }^{12}$. However, as a recent paper has reported that gefitinib prevents bleomycin-induced fibrosis in C57/ BL6 mice ${ }^{13}$, the effects of gefiitinib on lung injury 
A
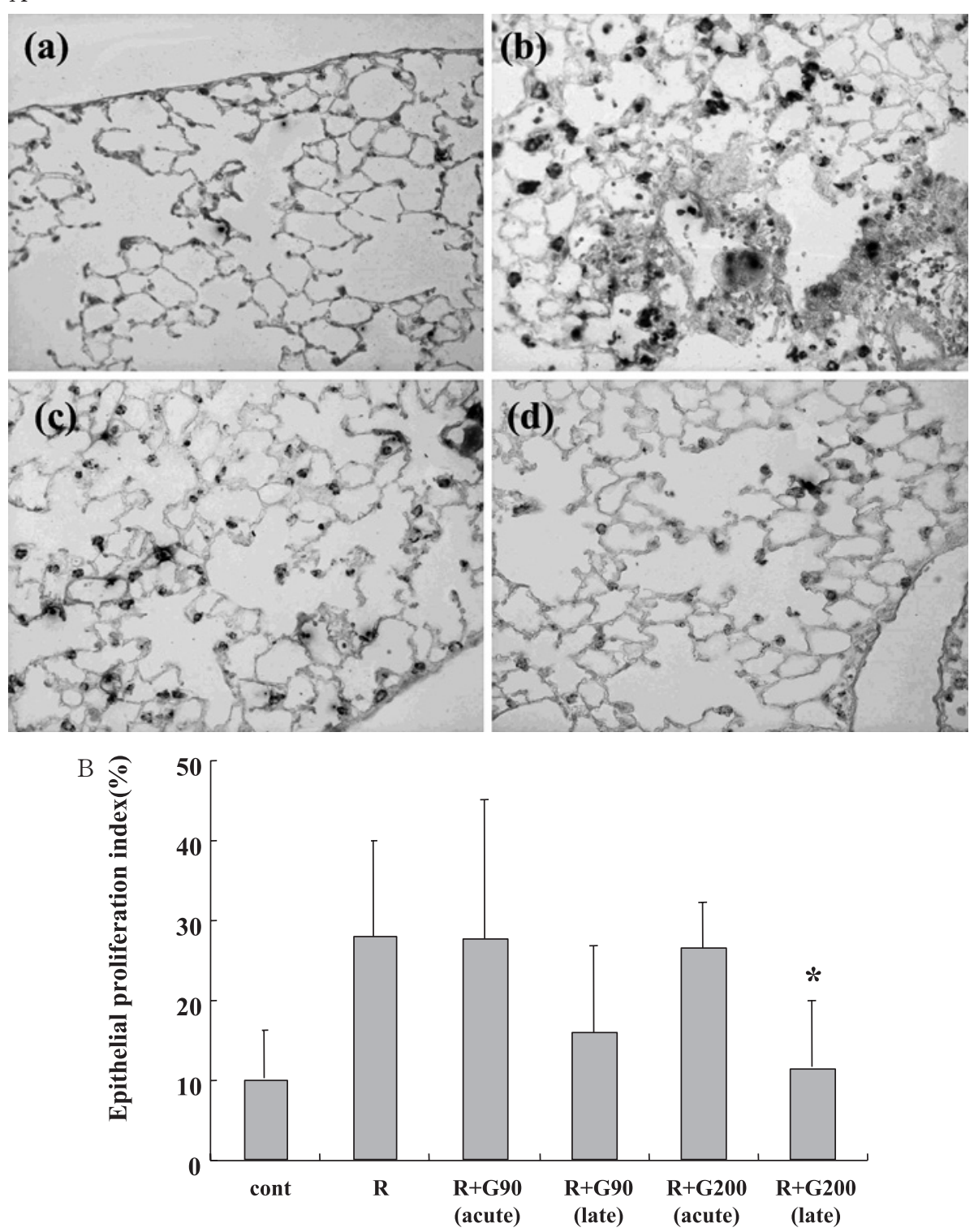

Fig. 4 Effect of gefitinib on epithelial cell proliferation

(A) Immunohistochemical staining of $\mathrm{PCNA}^{+} / \mathrm{SP}_{-} \mathrm{C}^{+}$in lung tissues from mice obtained 5 months post-radiation. (a) Control (vehicle, $0.1 \%$ Tween solution), (b) radiation only (12 Gy), (c) gefitinib $(200 \mathrm{mg} / \mathrm{kg}$ ) administered in the acute phase postirradiation, (d) gefitinib (200 $\mathrm{mg} / \mathrm{kg}$ ) administered in the late phase postirradiation. Original magnification, $\times 400$. These photographs are representative of 5 mice in each group.

(B) Proportion of $\mathrm{PCNA}^{+} / \mathrm{SP}_{-} \mathrm{C}^{+}$epithelial cells. Control: vehicle $(0.1 \%$ Tween solution), R: radiation only (12 Gy), $\mathrm{R}+\mathrm{G} 90$ (acute): gefitinib $(90 \mathrm{mg} / \mathrm{kg}$ ) administered in the acute phase postirradiation, $\mathrm{R}+\mathrm{G} 200$ (acute): gefitinib $(200 \mathrm{mg} / \mathrm{kg})$ administered in the acute phase postirradiation, R+G90 (late): gefitinib $(90 \mathrm{mg} / \mathrm{kg}$ ) administered in the late phase postirradiation, $\mathrm{R}+\mathrm{G} 200$ (late): gefitinib $(200 \mathrm{mg} / \mathrm{kg}$ ) administered in the late phase postirradiation. High-dose $(200 \mathrm{mg} / \mathrm{kg} / \mathrm{d})$ gefitinib in the late phase significantly reduced the proportion of $\mathrm{PCNA}^{+} / \mathrm{SP}_{-} \mathrm{C}^{+}$epithelial cells compared with radiation only $(\mathrm{p}=0.018)$.

and fibrosis remain controversial. To mimic the clinical situation, a radiation-induced lung injury model was used in this study. To clarify the effects of gefitinib on lung injury and fibrosis, the same doses were used $(20,90$, and $200 \mathrm{mg} / \mathrm{kg} /$ day) as in previous reports ${ }^{12,13}$.

Both EGF and EGFR have been reported to be expressed by type II pneumocytes, suggesting an autocrine regulation of type II pneumocytes ${ }^{14}$. The expression of EGFR has been reported to increase in 
A
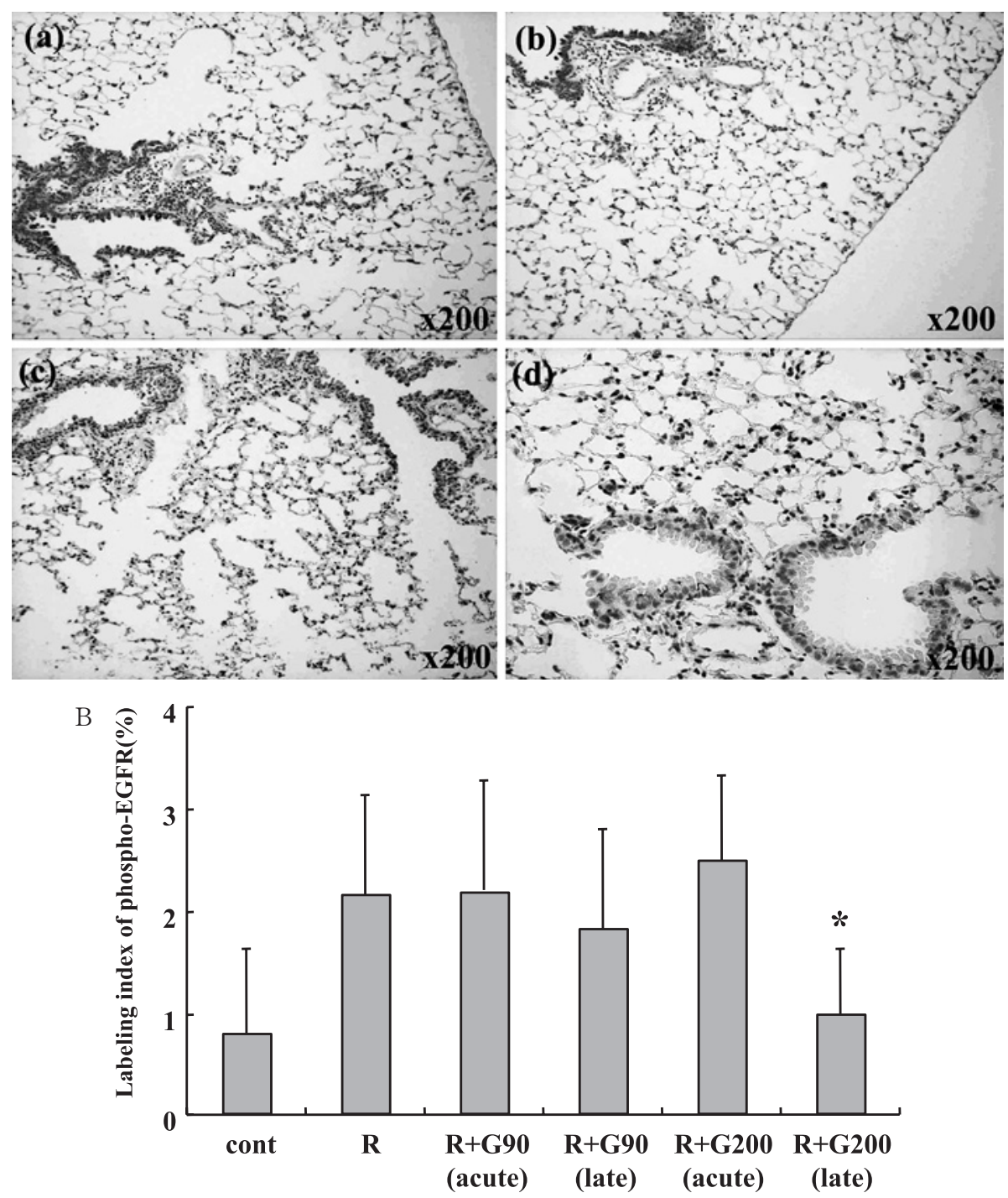

Fig. 5 Immunohistochemical staining for EGFR and p-EGFR

(A) Immunohistochemical staining for EGFR and p-EGFR in lung tissues from mice obtained 5 months postirradiation. (a) Immunostaining for EGFR in the lung postirradiation (12 Gy) only. Airway epithelial cells and type II pneumocytes were immunostained for EGFR. (b) Immunostaining for EGFR in the lung with administration of gefitinib $(200 \mathrm{mg} / \mathrm{kg})$ in the late phase postirradiation. Gefitinib did not change the expression of EGFR induced by irradiation. (c) Immunostaining for p-EGFR postirradiation only (12 Gy). (d) Immunostaining for p-EGFR in the lung with administration of gefitinib in the late phase postirradiation. Gefitinib tended to reduce the expression of $\mathrm{p}$-EGFR induced by irradiation. Original magnification, $\times 200$. These photographs are representative of 5 mice in each group.

(B) Proportion of p-EGFR-positive epithelial cells. Control: vehicle (0.1\% Tween solution), $\mathrm{R}$ : radiation only (12 Gy), $\mathrm{R}+\mathrm{G} 90$ (acute): gefitinib $(90 \mathrm{mg} / \mathrm{kg}$ ) administered in the acute phase postirradiation, $\mathrm{R}+\mathrm{G} 200$ (acute): gefitinib $(200 \mathrm{mg} / \mathrm{kg}$ ) administered in the acute phase postirradiation, $\mathrm{R}+\mathrm{G} 90$ (late): gefitinib $(90 \mathrm{mg} / \mathrm{kg}$ ) administered in the late phase postirradiation, $\mathrm{R}+\mathrm{G} 200$ (late): gefitinib $(200 \mathrm{mg} / \mathrm{kg})$ administered in the late phase postirradiation. High-dose $(200 \mathrm{mg} / \mathrm{kg} / \mathrm{d})$ gefitinib in the late phase significantly reduced the proportion of p-EGFR-positive epithelial cells compared with radiation only $(\mathrm{p}=0.0054)$.

bleomycin-induced lung injury ${ }^{15,16}$. In the rat, tyrosine kinase inhibitors specific for EGFR or platelet- derived growth factor (PDGF) have been reported to reduce the proliferation of myofibroblasts and inhibit 


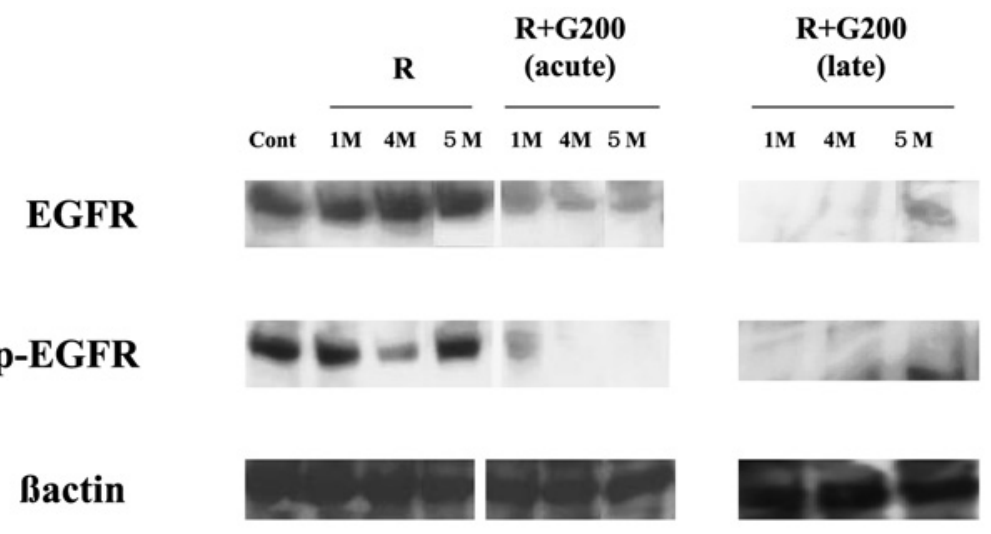

Fig. 6 Expression of EGFR and p-EGFR

Time courses of EGFR and p-EGFR expression in lung tissues were determined with Western blot analysis. Mice treated with or without gefitinib $(200 \mathrm{mg} / \mathrm{kg})$ in both the acute and late phases were killed 1, 2, 4, and 5 months postirradiation. Lung-tissue homogenates were analyzed for expression of EGFR and p-EGFR with Western blotting. Gefitinib treatment $(200 \mathrm{mg} / \mathrm{kg})$ in both phases inhibited the expression of EGFR and p-EGFR 4 and 5 months postirradiation.

pulmonary fibrosis following injury with vanadium pentoxide $\left(\mathrm{V}_{2} \mathrm{O}_{5}\right)^{17}$. Similar results were observed in the present study. High-dose gefitinib $(200 \mathrm{mg} / \mathrm{kg} /$ day) administered during the late phase significantly decreased the lung fibrosis score and collagen deposition, probably thorough inhibitory effects of gefitinib on irradiation-induced cell proliferation. Suzuki et al. have reported that gefitinib inhibits the proliferation of alveolar epithelial cells ${ }^{12}$, and it is, therefore, possible that gefitinib partly inhibits the ability of epithelial cells to respond to lung injury. However, we have demonstrated that gefitinib, except high-dose gefitinib $(200 \mathrm{mg} / \mathrm{kg} / \mathrm{d})$ administered during the late phase, does not reduce the number of irradiation-induced $\mathrm{PCNA}^{+} / \mathrm{SP}_{-} \mathrm{C}^{+}$ alveolar cells; this finding suggests a minimal effect of gefitinib on alveolar cell proliferation in this irradiation model. Ishi et al. have recently reported that gefitinib at any dose $(20,90$, and $200 \mathrm{mg} / \mathrm{kg} /$ day) significantly reduces the bleomycin-induced lung collagen accumulation ${ }^{13}$. In the present study, we demonstrated that only the high-dose gefitinib $(200 \mathrm{mg} / \mathrm{kg} / \mathrm{d}$ ) during the late phase significantly inhibits lung fibrosis and collagen deposition induced by irradiation. Unlike bleomycin-induced lung injury, protein-rich edema and hyaline membranes were features of radiation-induced injury in C57BL/6 mice $^{7}$. The collagen content (70 $\mu \mathrm{g}$ per right lung) induced by irradiation in the present study was much smaller than in previous reports ${ }^{12,13}$. Lung injury induced by a single dose of irradiation (12 Gy) might be mild for a drug intervention experiment. In addition, in this experimental model, chronic lung injury and fibrosis were longer lasting than in previous reports ${ }^{12.13}$. Gefitinib administration (20 and $90 \mathrm{mg} / \mathrm{kg} /$ day), even in the late phase (days 14-19), might not inhibit subsequent collagen accumulation (e.g., 5 months postirradiation). These results suggest that gefitinib does not exacerbate irradiation-induced lung fibrosis. These data are consistent with a recent clinical report that demonstrated that prior thoracic radiotherapy is not a risk factor for interstitial lung disease in patients treated with gefitinib $^{18}$. High-dose gefitinib $(200 \mathrm{mg} / \mathrm{kg} /$ day) might improve lung injury and fibrosis induced by irradiation. However, $200 \mathrm{mg} / \mathrm{kg} /$ day of gefitinib is much higher than the clinical dose $(250 \mathrm{mg} /$ body/ day), suggesting that it is impossible to apply the results of this study for clinical use. As shown in Figure 6, gefitinib (90 and $200 \mathrm{mg} / \mathrm{kg}$ ) in both phases significantly inhibited the expression of pEGFR induced by irradiation. The cytodifferentiation of type II alveolar cells is reported to be regulated by EGF and $\mathrm{EGFR}^{14.19}$. Inhibition of p-EGFR by highdose gefitinib could inhibit cell proliferation of type II alveolar cells and, therefore, may contribute to the 
antifibrosis effect.

The incidence of lung injury associated with gefitinib treatment in Japanese patients $(1.8 \%-5.4 \%)$ is much higher than that in non-Japanese patients ${ }^{5}$. In a recent first-line trial with gefitinib in Japan, the incidence of severe interstitial pneumonia was $10 \%{ }^{20}$. Although ethnic differences in the response to gefitinib have been reported, lung injury associated with gefitinib is unlikely to be related to the presence of an EGFR mutation ${ }^{21}$. The reason for the higher incidence of lung injury associated with gefitinib treatment in Japanese patients remains unknown. In mice, genetic backgrounds have been reported to affect the expression of EGFR in epithelial cells, suggesting that mouse strains may affect the response to gefitinib ${ }^{22}$. Two previous reports have demonstrated different effects of gefitinib in bleomycin-induced lung injuries using different mouse strains ${ }^{12,13}$. Furthermore, differences in $\mathrm{H} 2$ typing have been reported to affect the response to lung injury in mice $^{23}$. Further studies with other mouse strains will be needed to investigate the effects of gefitinib on lung injury and fibrosis.

In summary, gefitinib did not exacerbate radiation-induced lung injury and fibrosis in this study. These data suggest that thoracic irradiation is unlikely to be a risk factor for lung injury associated with gefitinib treatment. Further clinical studies are needed to confirm the safety of gefitinib in combination with radiotherapy. It is also important to clarify the mechanism of lung injury associated with gefitinib, including the underlying genetic issues.

\section{References}

1. Fukuoka M, Yano S, Giaccone G, et al.: Multiinstitutional randomized phase II trial of gefitinib for previously treated patients with advanced non-smallcell lung cancer. J Clin Oncol 2003; 21: 2273-2246.

2. Kris MG, Natale RB, Herbst RS, et al: Efficacy of gefinitib, an inhibitor of the epidermal growth factor receptor tyrosine kinase, in symptomatic patients with non-small cell lung cancer: a randomized trial. JAMA 2003; 290: 2149-2158.

3. Baselga J: Targeting the epidermal growth factor receptor with tyrosine kinase inhibitors: Small molecules, big hope. J Clin Oncol 2002; 20: 2217-2219.
4. Inoue A, Saijyo Y, Maemondo M, et al.: Severe acute interstitial pneumonia and gefitinib. Lancet 2003; 361: 137-139.

5. Takano T, Ohe Y, Kusumoto M, et al:: Risk factors for interstitial lung disease and predictive factors for tumor response in patients with advanced non-small cell lung cancer treated with gefitinib. Lung Cancer 2004; 45: 93-104.

6. Camus P, Kudoh S, Ebina M: Interstitial lung disease associated with drug therapy. Brtish J Cancer 2004; 91: S18-S23.

7. Rube CE, Uthe D, Schmid KW, et al: Dosedependent induction of transforming growth factor $\beta$ (TGF- $\beta$ ) in the lung tissue of fibrosis-prone mice after thoracic irradiation. Int J Radiation Oncology Biol Phys 2000; 47: 1033-1042.

8. Ashcroft T, Simpson JM, Timbrell V: Simple method for estimating the severity of pulmonary fibrosis on a numerical scale. J Clin Pathol 1988; 41: 467-470.

9. Phillips RJ, Burdick MD, Hong K, et al.: Circulating fibrocytes traffic to the lungs in response to CXCL 12 and mediate fibrosis. J Clin Invest 2004; 114: 438446.

10. Putti TC, To KF, Hsu HC, et al: Expression of epidermal growth factor receptor in head and neck cancers correlates with clinical pregression: a multicenter immnohistochemical study in the AsiaPacific region. Histopathology 2002; 41: 144-151.

11. Eunjoo HL, Choun-Ki J: Role of transforming growth factor- $\beta$ in transdifferentiation and fibrosis of lens epithelial cells. Investigative Ophthalmology and Visual Sciences 1999; 40: 2025-2032.

12. Suzuki H, Aoshiba K, Yokohori N, Nagai A: Epidermal growth factor receptor tyrosine kinase inhibition augments a murine model of pulmonary fibrosis. Cancer Res 2003; 63: 5054-5059.

13. Ishi Y, Fujimoto S, Fukuda Y: Gefitinib prevents bleomycin-induced lung fibrosis in mice. Am J Respir Crit Care Med (in press) as doi: 10.1164/rccm.20050915340C.

14. Raaberg L, Nexo E, Buckley S, et al: Epidermal growth factor transcription, translation and signal transduction by rat type II pneumocytes in culture. Am J Respir Cell Mol Biol 1992; 6: 44-49.

15. Madtes FH, Bubsy HK, Strndjord TP, et al: Expression of transforming growth factor- $\alpha$ and epidermal growth factor receptor is increased following bleomycin-induced lung injury in rats. Am J Respir Cell Mol Biol 1994; 11: 540-551.

16. Baughman RP, Lower EE, Miller MA, Bejarano PA, Heffelfinger SC: Over-expression of transforming growth factor-a and epidermal growth factorreceptor in idiopathic pulmonary fibrosis. Sarcoidosis Vasc. Diffuse Lung Dis 1999; 16: 57-61.

17. Rice AB, Moomaw CR, Morgan DL, et al.: Specific inhibitors of platelet-derived growth factor or epidermal growth factor receptor tyrosine kinase reduce pulmonary fibrosis in rats. Am J Pathol 1999; 155: 213-221.

18. Takano T, Ohe Y, Kusumooto M, et al.: Risk factors for interstitial lung disease and predictive factors for tumor response in patients with advanced non-small cell lung cancer treated with gefitinib. Lung Cancer 2004; 45: 93-104.

19. Plopper CG, St George JA, Read LC, et al.: 
Acceleration of alveolar type II cell differentiation in fetal rhesus monkey lung by administarion of EGF. Am J Physiol 1992; 262: L313-321.

20. Niho S, Kubota K, Goto K, et al.: First-line single agent treatment with gefitinib in patients with advanced non-small-cell lung cancer: a phase II study. J Clin Oncol 2006; 24: 64-69.

21. Calvo E, Baselga J: Ethnic differences in response to epidermal growth factor receptor tyrosine kinase inhibitors. J Clin Oncol 2006; 24: 2158-2163.

22. Sibilia M, Wagner EF: Strain-dependent epithelial defects in mice lacking the EGF receptor. Science 1995; 269: 234-238.

23. Du M, Irani RA, Stivers DN, et al.: H2-Ea deficiency is a risk factor for bleomycin-induced lung fibrosis in mice. Cancer Res 2004; 64: 6835-6839.

(Received, December 17, 2007)

(Accepted, January 10, 2008) 